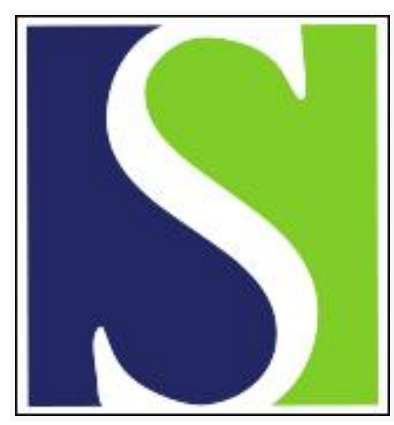

Scand J Work Environ Health 1998;24(1):30-37

https://doi.org/10.5271/sjweh.275

Issue date: Feb 1998

Metabolic interaction between toluene, trichloroethylene and n-hexane in humans

by Bælum J, Mølhave L, Honoré Hansen S, Væth M

Key terms: end exhaled air; flow limitation; metabolite

This article in PubMed: www.ncbi.nlm.nih.gov/pubmed/9562398

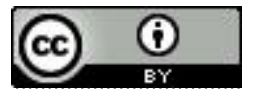




\title{
Metabolic interaction between toluene, trichloroethylene and n-hexane in humans
}

by Jesper Bælum, MD, ${ }^{1}$ Lars Mølhave, PhD, ${ }^{1}$ Steen Honoré Hansen, DSc, ${ }^{2}$ Michael Væth, PhD ${ }^{3}$

\begin{abstract}
Bælum J, Mølhave L, Honoré Hansen S, Væth M. Metabolic interaction between toluene, trichloroethylene and n-hexane in humans. Scand J Work Environ Health 1998;24(1):30-7

Objectives This human experimental study describes the mutual metabolic interaction between toluene, trichloroethylene, and n-hexane.

Methods Eight healthy male volunteers were exposed to combinations of toluene $(1.5$ or $4 \mathrm{mg} / \mathrm{min}$ ), trichloroethylene $(1.5$ or $4 \mathrm{mg} / \mathrm{min})$, and $\mathrm{n}$-hexane $(0.3$ or $1.0 \mathrm{mg} / \mathrm{min})$ for $60 \mathrm{~min}$. End exhaled air concentrations were measured before and up to $240 \mathrm{~min}$ after the start of exposure. The urinary excretion of hippuric acid, o-cresol, trichloroethanol, trichloroacetic acid, and 2,5-hexanedione was measured before and up to $270 \mathrm{~min}$ after the start of the exposures.

Results When the low dose rates were combined, the end exhaled concentrations were at or below the detection limit, while an increase in the dose rate of toluene increased the area under the end exhaled air concentration curve (AUC) of toluene, trichloroethylene, and n-hexane by factors of 44 (16-117) [geometric mean and 95\% confidence interval], $12.8(4.1-40.0)$, and $2.2(1.2-4.1)$, respectively. Trichloroethylene, in turn, increased the AUC 5.0 (1.9-13.4), $25.8(8.2-80.8)$ and 2.9 (1.6-5.4), respectively, whereas the corresponding values for n-hexane were $1.9(0.7-5.1), 1.5(0.5-4.6)$, and 3.2 (1.8-5.9). An 18 (range 2-34)\% decrease in hippuric acid was the only interaction measured in the metabolite excretion. No correlation occurred between the individual measures of the end exhaled concentrations or the excretion of metabolites.

Conclusions The study shows that the threshold for the flow-limited metabolism of the 3 solvents in humans is exceeded at liver dose rates corresponding to inhalation exposure at occupational exposure limits. At these levels there are metabolic interactions between the 3 solvents.
\end{abstract}

Key terms end exhaled air, flow limitation, metabolites.

Industrial exposures to combinations of solvents are very common. Most of the solvents are metabolized in the liver, the initial step being mediated by the cytochrome P450 (CYP) system (1). This system has a limited metabolic capacity, and therefore interaction phenomena between the different solvents are possible depending on the cytochrome P450 isoenzymes involved.

Toluene, trichloroethylene, and n-hexane are well known and widely used industrial solvents. The metabolism of the substances is relatively well known. Toluene is mainly oxidized in the side chain to benzoic acid and conjugated with glycin to hippuric acid, while a minor fraction is oxidized in the ring to cresols (2). Trichloroethylene is metabolized via chloral hydrate to trichloroethanol and trichloroacetic acid (3), while n-hexane is metabolized via both primary and secondary alcohols to ketones and diketones, of which 2,5- hexanedione, a well known neurotoxin, has been extensively studied (4).

In a previous experiment we used gastrointestinal exposure to study the metabolism of toluene and the interaction between ethanol and toluene in humans (5). The results showed that, at liver dose rates of $2 \mathrm{mg}$ of toluene per minute, the hepatic extraction ratio was very high but decreased sharply when the dose rate was increased to $6 \mathrm{mg} /$ min. This finding indicates that, between these dose rates, there is a shift from flow-limited to enzyme-limited metabolism. Ethanol given orally in very low doses had a considerable and dose-related inhibitory effect on toluene metabolism.

Our present study is an experiment using volunteers and aimed at studying the mutual interactions between toluene, trichloroethylene, and n-hexane in humans using dose rates

1 Institute of Environmental and Occupational Medicine, University of Aarhus, Århus, Denmark.

2 Royal Danish School of Pharmacy, København, Denmark.

3 Department of Biostatistics, University of Aarhus, Århus, Denmark.

Reprint requests to: Dr Jesper Bælum, Department of Occupational and Environmental Medicine, Odense University Hospital, DK-5000 Odense C, Denmark. 
to the liver comparable with those obtained by the inhalation of concentrations at the actual Danish occupational exposure limits [ $50 \mathrm{ppm}$ for toluene, $30 \mathrm{ppm}$ for trichloroethylene, and $50 \mathrm{ppm}$ for $\mathrm{n}$-hexane in 1992 (6)] in combination with light exercise $(50 \mathrm{~W})$.

The hypotheses were that, for both trichloroethylene and n-hexane, a shift from flow-limited to enzyme-limited metabolism analogous to that of toluene is seen and for all the substances this threshold is altered by a change in one or both of the other substances (metabolic interaction). In addition there may be mutual interaction on the excretion of the metabolites of the 3 substances due to a competition for common isoenzymes.

The study was approved by the Scientific Ethical Committee of Aarhus County, Denmark.

\section{Material and methods}

\section{Experimental design}

In 48 sessions 8 volunteers were exposed to the combinations of toluene $(1.5 \mathrm{or} 4 \mathrm{mg} / \mathrm{min})$, trichloroethylene $(1.5$ or $4 \mathrm{mg} / \mathrm{min}$ ), and $\mathrm{n}$-hexane $(0.3$ or $1.0 \mathrm{mg} / \mathrm{min})$ for $60 \mathrm{~min}$.

The set-up was a $2^{3}$ factorial design with factors representing the 3 solvents each at 2 dose rates. Originally, the study was planned as an incomplete block design with $4 \mathrm{ex}-$ posures allocated to each of 12 persons (7). However, 4 subjects were able to carry through all 8 exposure combinations, while the other 4 each went through 4 combinations. The study design was therefore a combination of a complete design with 4 replications (persons) and an incomplete design with 4 blocks. One effect in the design (interaction between toluene and $n$-hexane) was therefore partially confounded by the difference between the subjects (7).

Table 1 shows the 7 statistical effects which can be estimated from the $2^{3}$ factorial design, as well as the scheme for calculating the effects from the combinations of exposure.

The setting of dose rates for toluene was based on the results of our previous study (5), $1.5 \mathrm{mg} / \mathrm{min}$ being below the dose rate where the liver can extract all the substance while at $4.0 \mathrm{mg} / \mathrm{min}$ the capacity in some subjects may be exceeded. In pilot exposures $2 \mathrm{mg}$ of trichloroethylene and $1 \mathrm{mg}$ of $\mathrm{n}$-hexane per minute did not give measurable end exhaled air concentrations. Therefore the dose rates of trichloroethylene were set at 1.5 and $4.0 \mathrm{mg} / \mathrm{min}$ as an analogue to toluene, while the dose rates of n-hexane were set at 0.3 and $1.0 \mathrm{mg} / \mathrm{min}$ due to the much lower Ostwald blood:air partition coefficient $(0.8$ versus 15 and 10$)$ and thereby to lower liver dose rates at the same inhalation concentrations $(8,9)$.

\section{Subjects}

The 8 male subjects were between 22 and 28 (mean 24.0) years of age. Their body weight ranged from 72 to 84 (mean 73.9 ) $\mathrm{kg}$ and their body mass indices from 20 to 25 (mean
22.5) $\mathrm{kg} / \mathrm{m}^{2}$. All 8 subjects were nonsmokers without any history of liver disease or regular drug consumption, and they were moderate users of alcohol $(<40 \mathrm{~g} /$ week pure alcohol). Before entering the study, all the subjects went through a medical examination including blood tests. All the tests, including serum concentrations of alanine amino transferase, aspartate amino transferase, bilirubin, alkaline phosphatases, and coagulation factors II, VII and X (prothrombin time), were all normal, and none of the subjects had hepatitis B antibodies.

Before each exposure session the subjects had avoided alcohol for the last 3 days and sports activities were avoided within the last 24 hours. On the day of the exposure session they were told to avoid milk and products containing benzoic acid at breakfast. At least 7 days should have passed since any acute illness or intake of medicine. The exposures of the individual subjects were separated by at least 3 days.

\section{Exposure}

The solvents were given through a feeding tube (Flocare, $\mathrm{CH} 8$, Nutricia, Vermeeren, The Netherlands) using a variable laboratory pump, as in our previous study (5). The tube was inserted through the nose to a depth of $110 \mathrm{~cm}$ and the position in the stomach was controlled by auscultation during air insufflation.

The 8 combinations of mixtures of the 3 solvents (spectroscopy grade) were mixed before the start of the study and kept refrigerated in sealed glass bottles until the day of the individual experiment. The calculated amount of the

Table 1. Seven within-subject effects estimated in the $2^{3}$ factorial design. The second column shows the abbreviations used in tables 2 to 4 . The third column shows how these effects were calculated from the different exposure combinations given to each subject. The toluene - hexane interaction was estimated from the four subjects exposed to the full series of exposure combinations. $[\mathrm{t}, \mathrm{c}$, and $\mathrm{h}=$ high dosage of the exposure $(4.0 \mathrm{mg} / \mathrm{min}$ for toluene and trichloroethylene, and $1.0 \mathrm{mg} / \mathrm{min}$ for $\mathrm{n}$-hexane, $\cdot=$ low dose rates $(1.5,1.5$, and $0.3 \mathrm{mg} / \mathrm{min}$, respectively]

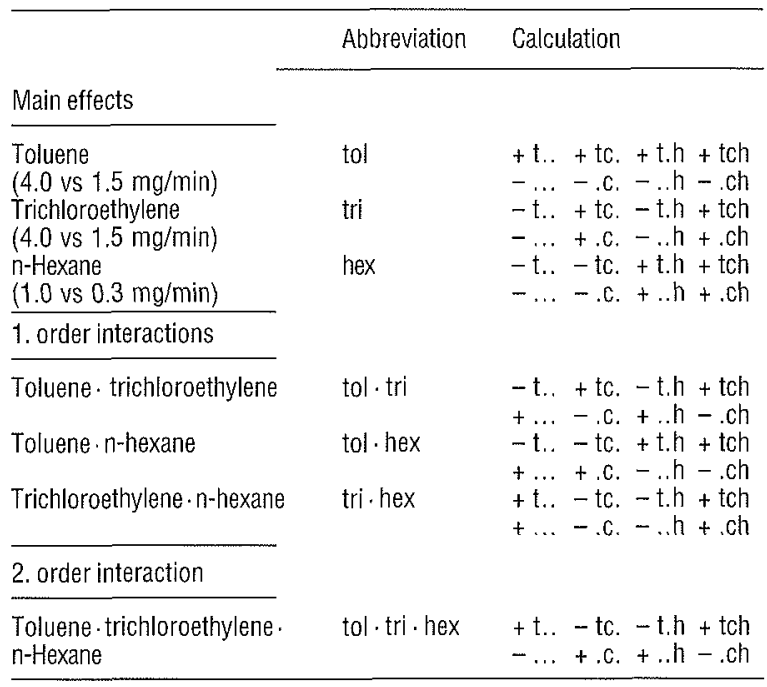

Scand J Work Environ Health 1998, vol 24, no 1 
mixture was dissolved in $300 \mathrm{ml}$ of a commercial tube feeding product (Nutrison, Nutricia, Vermeeren, The Netherlands), and $0.4 \mathrm{ml}$ of an emulgator (polysorbat 80 ) was added.

\section{Measurements}

Toluene, trichloroethylene and n-hexane in end exhaled air. End expiratory air samples were collected in $250-\mathrm{ml}$ preheated glass pipettes (5). Before the air sample was collected, the subject made a maximal inspiration and held his breath for 15 seconds. Including the duration of expiration gave a total time of breathholding of about 25 seconds to achieve equilibrium between the blood and end exhaled air. Samples were taken before $(0)$ as well as $30,45,60,90,150$, and 240 minutes after the start of the exposure.

The concentrations of toluene, trichloroethylene, and n-hexane were measured by gas chromatography-mass spectrometry after cryofocusing within 2 hours after the sampling. With the use of preheated $\left(45^{\circ} \mathrm{C}\right) 0.5$ - to $20-\mathrm{ml}$ precision sampling injection syringes (Pressure Lock series), air samples were taken from the pipettes and injected directly into the heated sample container of a Tekmar model 5010 automatic desorber during the desorption phase. The desorber was connected to a HP 5930A-GC/MS machine containing a Carbowax 20M 25-m capillary column, which was run at a constant temperature of $40^{\circ} \mathrm{C}$ in a HP 5700 gas chromatograph. Masses from 46 to 110 were sampled in the online program and stored. The identification of toluene, trichloroethylene, and n-hexane in the mass chromatogram was based on retention times and the appearance of masses 91, 95 and 57 , respectively. The quantification was made by calculating the area of these ion mass peaks. The analytical equipment was calibrated with a standard gas [toluene 5.6 (SD 0.3) ppm, trichloroethylene 7.3 (SD 0.4) ppm, and n-hexane 8.7 (SD 0.4) ppm] in synthetic air (AGA Stockholm, Sweden). The detection limit for all the substances was the $0.5 \mathrm{ng}$ equivalent to an end exhaled concentration of $0.025 \mathrm{mg} / \mathrm{m}^{3}$.

Metabolites. The urine was quantitatively sampled in 5 periods, one before exposure and 60, 120180 , and $270 \mathrm{~min}$ after the start.

Concentrations of hippuric acid and $o$-cresol were measured by earlier described high-performance liquid chromatographic methods (10). In the present study the detection limit was $0.2 \mathrm{mmol} / \mathrm{l}$ for hippuric acid and $0.3 \mu \mathrm{mol} / \mathrm{l}$ for o-cresol. The analytical variation calculated as the coefficient of variation between double measurements on separate days of analysis was $6.7 \%$ for hippuric acid and $10.8 \%$ for o-cresol.

Trichloroethylene and the metabolites trichloroethanol (TCE) and trichloroacetic acid (TCA) were analyzed by the gas chromatographic method of Christensen et al with slight modifications (11). The detection limits of TCE and TCA were 0.5 and $0.2 \mu \mathrm{g} / \mathrm{ml}(0.034$ and $0.012 \mathrm{mmol} / \mathrm{l})$, respectively, and the coefficient of variation of double measurements on separate days of analysis was $17 \%$ for TCE and $11 \%$ for TCA. Within the same day the coefficients of variation were 9.5 and $7.6 \%$, respectively. All measurements from the same subject were therefore analyzed within the same day. The detection limit for trichloroethylene was $0.1 \mu \mathrm{g} / \mathrm{ml}(0.006 \mathrm{mmol} / \mathrm{l})$.

2,5-Hexanedione was analyzed by a method developed by van Engelen et al (12). The method was based on the derivatization of 2,5-hexanedione without prior acid hydrolysis with $0-2,3,4,5,6$-pentafluorobenzyl) hydroxylamine followed by liquid-liquid extraction with cyclohexane followed by analysis on a gas chromatograph with an electron-capture detector. The lower limit of quantification was $0.05 \mu \mathrm{mol} / \mathrm{l}$, and the values were calculated from double measurements made on separate days with a coefficient of variation of $4.7 \%$.

\section{Calculations}

The areas under the end exhaled air concentration curves (AUC) were estimated by the trapezoid rule without calculation of the tail area. For the metabolites the excretion rates in each period, as well as the total excretion from the start of exposure, were calculated. In all the calculations, the values below the detection limits were set at 0.5 times this value.

\section{Statistical analysis}

The main outcome variables were the AUC for the 3 solvents and the total excretion of the 5 different metabolites. An analysis of variance was applied to the data for each of these variables (7). The AUC data were log-transformed prior to the analysis to ensure that the data complied with the assumptions of homogeneity of variance.

Estimates and $95 \%$ confidence intervals for main effects (effect of the change of dose rate of the 3 solvents on the outcome) and interactions were used to summarize the results of the analysis of variance (7). For the AUC data the main effects and interactions are expressed as a proportional change; thus an effect is significant at a 5\% level if 1 is not included in the $95 \%$ confidence interval. For the excretion data the main effects and interactions are presented as a percental change, and an effect is significant at a $5 \%$ level if 0 is not included in the $95 \%$ confidence interval.

Furthermore, to evaluate the time course of the effects of the 3 solvents on the end exhaled concentrations and the excretion of the metabolites, separate analyses of variance were performed on data from each sampling time. The end exhaled concentrations were log-transformed prior to the analysis.

\section{Results}

Estimates of the main effects and interactions for the AUC of the end exhaled concentrations and the total excretion of 
Table 2. Main effects and interactions of the exposure on the area under the curve (AUC) of the end exhaled toluene concentrations and the total excretion of hippuric acid and 0 -cresol expressed as the proportional change in the exhaled air concentrations and the percentage of change in the metabolite excretion.

\begin{tabular}{|c|c|c|c|c|c|c|}
\hline \multirow[t]{2}{*}{ Effect $^{2}$} & \multicolumn{2}{|c|}{ Toluene in exhaled air } & \multicolumn{2}{|c|}{ Hippuric acid in urine } & \multicolumn{2}{|c|}{ o-Cresol in urine } \\
\hline & Proportion & $\begin{array}{c}95 \% \\
\text { confidence } \\
\text { interval }\end{array}$ & $\begin{array}{l}\text { Percentage } \\
\text { of change }\end{array}$ & $\begin{array}{c}95 \% \\
\text { confidence } \\
\text { interval }\end{array}$ & $\begin{array}{l}\text { Percentage } \\
\text { of change }\end{array}$ & $\begin{array}{c}95 \% \\
\text { confidence } \\
\text { interval }\end{array}$ \\
\hline $\begin{array}{l}\text { tol } \\
\text { tri } \\
\text { tol } \cdot \text { tri } \\
\text { hex } \\
\text { tol. hex } \\
\text { tri-hex } \\
\text { tol.tri.hex }\end{array}$ & $\begin{array}{r}43.7 \\
5.0 \\
0.9 \\
1.9 \\
1.8 \\
1.6 \\
0.7\end{array}$ & $\begin{array}{l}16.4-116.7 \\
1.9-13.4 \\
0.3-2.4 \\
0.7-5.1 \\
0.5-5.9 \\
0.6-4.3 \\
0.3-1.9\end{array}$ & $\begin{array}{r}47 \\
-4 \\
0 \\
-18 \\
2 \\
8 \\
-4\end{array}$ & $\begin{array}{c}31-63 \\
-20-12 \\
-16-16 \\
-34--2 \\
-18-21 \\
-8-24 \\
-20-12\end{array}$ & $\begin{array}{r}72 \\
11 \\
-1 \\
-1 \\
-11 \\
20 \\
17\end{array}$ & $\begin{array}{r}47-97 \\
-14-36 \\
-26-24 \\
-26-24 \\
-41-20 \\
-5-45 \\
-8-42\end{array}$ \\
\hline Mean & \multicolumn{2}{|c|}{$49.35 \mathrm{mg} / \mathrm{m}^{3} \cdot \mathrm{min}^{\mathrm{b}}$} & \multicolumn{2}{|l|}{$2237 \mu \mathrm{mol}$} & \multicolumn{2}{|l|}{$1.66 \mu \mathrm{mol}$} \\
\hline SD between subjects & \multicolumn{2}{|c|}{$2.56 \mathrm{mg} / \mathrm{m}^{3} \cdot \mathrm{min}^{\mathrm{h}}$} & \multicolumn{2}{|l|}{$469 \mu \mathrm{mol}$} & \multicolumn{2}{|l|}{$0.42 \mu \mathrm{mol}$} \\
\hline $\begin{array}{l}\text { Residual mean square error } \\
\text { within subjects }\end{array}$ & \multicolumn{2}{|c|}{$5.67 \mathrm{mg} / \mathrm{m}^{3} \cdot \mathrm{min}^{\mathrm{b}}$} & \multicolumn{2}{|l|}{$637 \mu \mathrm{mol}$} & \multicolumn{2}{|l|}{$0.73 \mu \mathrm{mol}$} \\
\hline
\end{tabular}

a See table 1.

b Geometric values.

Table 3. Main effects and interactions of the exposure on the area under the curve (AUC) of the end exhaled trichloroethylene concentrations and the total excretion of trichloroethanol and trichloroacetic acid expressed as the proportional change in the exhaled air concentrations and the percentage of change in the metabolite excretion.

\begin{tabular}{|c|c|c|c|c|c|c|}
\hline \multirow[t]{2}{*}{ Effect ${ }^{a}$} & \multicolumn{2}{|c|}{ Trichloroethylene in exhaled air } & \multicolumn{2}{|c|}{ Trichloroacetic acid in urine } & \multicolumn{2}{|c|}{ Trichloroethanol in urine } \\
\hline & Proportion & $\begin{array}{c}95 \% \\
\text { confidence } \\
\text { interval }\end{array}$ & $\begin{array}{l}\text { Percentage } \\
\text { of change }\end{array}$ & $\begin{array}{c}95 \% \\
\text { confidence } \\
\text { interval }\end{array}$ & $\begin{array}{l}\text { Percentage } \\
\text { of change }\end{array}$ & $\begin{array}{c}95 \% \\
\text { confidence } \\
\text { interval }\end{array}$ \\
\hline $\begin{array}{l}\text { tol } \\
\text { tri } \\
\text { tol. tri } \\
\text { hex } \\
\text { tol. hex } \\
\text { tri hex } \\
\text { tol.tri. hex }\end{array}$ & $\begin{array}{r}12.8 \\
25.8 \\
1.5 \\
2.1 \\
1.3 \\
1.4 \\
0.9\end{array}$ & $\begin{array}{l}4.1-40.0 \\
8.2-80.8 \\
0.5-4.6 \\
0.7-6.7 \\
0.3-5.2 \\
0.4-4.3 \\
0.3-2.9\end{array}$ & $\begin{array}{l}14 \\
12 \\
-5 \\
19 \\
30 \\
-6 \\
-4\end{array}$ & $\begin{array}{r}-21-48 \\
-23-47 \\
-40-30 \\
-23-62 \\
-5-65 \\
-41-29 \\
-20-12\end{array}$ & $\begin{array}{r}12 \\
50 \\
0 \\
-3 \\
3 \\
-7 \\
-3\end{array}$ & $\begin{array}{l}-10-21 \\
34-65 \\
-15-16 \\
-18-13 \\
-16-22 \\
-23-8 \\
-18-13\end{array}$ \\
\hline Mean & \multicolumn{2}{|c|}{$25.24 \mathrm{mg} / \mathrm{m}^{3} \cdot \mathrm{min}^{b}$} & \multicolumn{2}{|l|}{$4.57 \mu \mathrm{mol}$} & \multicolumn{2}{|l|}{$83.2 \mu \mathrm{mol}$} \\
\hline SD between subjects & \multicolumn{2}{|c|}{$2.55 \mathrm{mg} / \mathrm{m}^{3} \cdot \mathrm{min}^{b}$} & \multicolumn{2}{|l|}{$1.87 \mu \mathrm{mol}$} & \multicolumn{2}{|l|}{$7.3 \mu \mathrm{mol}$} \\
\hline $\begin{array}{l}\text { Residual mean square error } \\
\text { within subjects }\end{array}$ & \multicolumn{2}{|c|}{$7.54 \mathrm{mg} / \mathrm{m}^{3} \cdot \mathrm{min}^{\mathrm{b}}$} & \multicolumn{2}{|l|}{$2.82 \mu \mathrm{mol}$} & \multicolumn{2}{|l|}{$38.5 \mu \mathrm{mol}$} \\
\hline
\end{tabular}

See table 1.

Geometric values.

metabolites of each substance are shown in tables $2-4$. The average time course of the end exhaled concentrations and the excretion rates of the 3 main metabolites in relation to the main effects are shown in figures $1-3$.

Before the exposure the end exhaled concentrations of all the substances were below the detection limits. When the subjects were exposed to the low dose rates of the 3 substances, the end exhaled concentrations of all the substances were very low. When the dose rate of any of the 3 substances was increased, the end exhaled concentrations increased during exposure to a maximum $0-30$ min after the end of the exposure, decreasing thereafter to values close to the detection limits $180 \mathrm{~min}$ after the end of exposure. There was a considerable variation in the concentrations of toluene, ranging from 0 to $29 \mathrm{mg} / \mathrm{m}^{3}$, trichloroethylene, from 0 to $46 \mathrm{mg} / \mathrm{m}^{3}$, and $\mathrm{n}$-hexane, from 0 to $29 \mathrm{mg} / \mathrm{m}^{3}$.
Toluene and its metabolites. An increase in exposure to toluene significantly increased the end exhaled toluene concentration in all the samples during and after the exposure, the result being a 44-fold increase in the AUC (table 2). There was a significant effect of trichloroethylene on the toluene concentration in the samples at 30,45,60, 150, and $240 \mathrm{~min}$, while the effect of $n$-hexane was only significant at 45 and $60 \mathrm{~min}$ (figure 1). There was no significant second or higher order interactions.

The excretion of hippuric acid corresponded to $125 \%$ of the ingested dose of toluene before and $70 \%$ after correction for preexposure excretion of hippuric acid. The difference in hippuric acid excretion between the high and the low toluene dose rate was $1.06 \mathrm{mmol}$, or $65 \%$ of the change in toluene dose. An increase in the n-hexane dose rate decreased the hippuric acid excretion by $18 \%$, the main 
Table 4. Main effects and interactions of the exposure on the area under the curve (AUC) of the end exhaled $n$-hexane concentrations and the total excretion of 2,5-hexanedione expressed as the proportional change in the exhaled air concentrations and the percentage of change in the metabolite excretion.

\begin{tabular}{|c|c|c|c|c|}
\hline \multirow[t]{2}{*}{ Effecta } & \multicolumn{2}{|c|}{$\begin{array}{c}\text { n-Hexane } \\
\text { in exhaled air }\end{array}$} & \multicolumn{2}{|c|}{$\begin{array}{l}2,5 \text {-Hexanedione } \\
\text { in urine }\end{array}$} \\
\hline & Proportion & $\begin{array}{c}95 \% \\
\text { confidence } \\
\text { interval }\end{array}$ & $\begin{array}{l}\text { Percentage } \\
\text { of change }\end{array}$ & $\begin{array}{c}95 \% \\
\text { confidence } \\
\text { interval }\end{array}$ \\
\hline $\begin{array}{l}\text { tol } \\
\text { tri } \\
\text { tol tri } \\
\text { hex } \\
\text { tol. hex } \\
\text { tri. hex } \\
\text { tol tri - hex }\end{array}$ & $\begin{array}{l}2.2 \\
2.9 \\
1.8 \\
3.2 \\
2.0 \\
2.6 \\
2.0\end{array}$ & $\begin{array}{l}1.2-4.1 \\
1.6-5.4 \\
1.0-3.3 \\
1.8-5.9 \\
0.9-4.1 \\
1.4-4.7 \\
1.1-3.7\end{array}$ & $\begin{array}{r}-5 \\
-31 \\
-1 \\
83 \\
1 \\
-3 \\
-28\end{array}$ & $\begin{array}{l}-57-46 \\
-83-20 \\
-52-51 \\
31-135 \\
-63-64 \\
-55-49 \\
-80-23\end{array}$ \\
\hline $\begin{array}{l}\text { Mean } \\
\text { SD between } \\
\text { subjects }\end{array}$ & \multicolumn{2}{|c|}{$1.64 \mathrm{mg} / \mathrm{m}^{3} \cdot \mathrm{min}^{\mathrm{b}}$} & \multicolumn{2}{|l|}{$0.10 \mu \mathrm{mol}$} \\
\hline $\begin{array}{l}\text { Residual mean } \\
\text { square error } \\
\text { within subjects }\end{array}$ & \multicolumn{2}{|c|}{$2.91 \mathrm{mg} / \mathrm{m}^{3} \cdot \mathrm{min} \mathrm{n}^{\mathrm{b}}$} & \multicolumn{2}{|l|}{$0.20 \mu \mathrm{mol}$} \\
\hline
\end{tabular}

\section{a See table 1.}

b Geometric values.

effect occurring within the first 120 min after the start of exposure.

The $o$-cresol excretion corresponded to $0.092 \%$ of the toluene dose. There was no effect of either trichloroethylene or n-hexane.

Trichloroethylene and its metabolites. An increase in the trichloroethylene dose rate led to an increase in the end ex- haled concentration in all the samples, and the AUC was increased by a factor of 26 (table 3 ). There was a significant effect of toluene in the samples from 45 to 120 min and a significant effect of $\mathrm{n}$-hexane in the samples 45 and $60 \mathrm{~min}$ after the start of the experiment (figure 2).

No trichloroethylene could be detected in urine. The TCE excretion corresponded to $6.8 \%$ of the trichloroethylene dose, while the excretion of TCA corresponded to $0.45 \%$ of the dose. There was no effect of either toluene or n-hexane on the 2 metabolites. As the only metabolite, TCA was highly dependent on the time between exposures. This effect could be detected in all the samples before, during, and after the exposure. Only when this variable was included in the analysis was the effect of trichlorethylene on TCA excretion significant.

$n$-Hexane and its metabolites. The end exhaled concentrations of n-hexane were much lower than those of the other substances. The concentrations only exceeded the detection limit in the samples between 45 and 90 min and only when the high dose rate of $n$-hexane was combined with the high dose rate of one of the other substances. This occurrence gave rise to several significant effects, including the main effects of all 3 substances and interactions.

The excretion of 2,5-hexanedione corresponded to $0.052 \%$ of the n-hexane dose. There was no effect of either toluene or trichloroethylene.

Variation between subjects. For the 8 subjects the average total hippuric acid excretion varied from $13 \%$ to $97 \%$
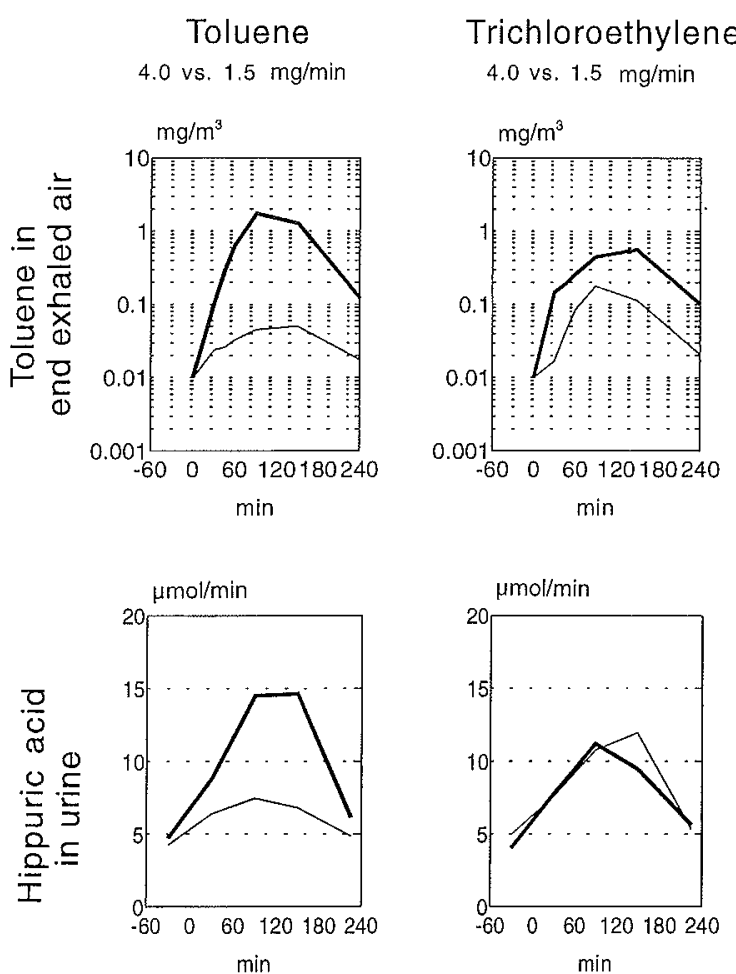
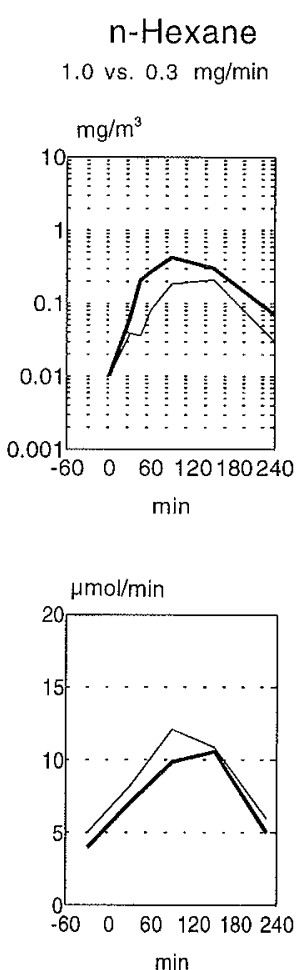

Figure 1. Estimates of the three main exposure contrasts - toluene, trichloroethylene, and $n$-hexane - on the end exhaled air concentration of toluene and the urinary excretion of hippuric acid. In each subchart the heavy line shows the average time course of the concentrations and excretion rates at the high dose rate levels while the thin line shows the values at the low dose rate. 
Figure 2. Estimates of the three main ethylene, and $n$-hexane - on the end exhaled air concentration of trichlorotrichloroethanol. In each subchart the heavy line shows the average time course of the concentration and excretion rates at the high dose rate levels, while the thin

Figure 3. Estimates of the three main exposure contrasts - toluene, trichloroexhaled air concentration of $n$-hexane, and the urinary excretion of 2,5-hexanedione. In each subchart the heavy line shows the average time course of the concentration and excretion rates at the high dose rate levels, while the thin line shows the values at the low dose rate. exposure contrasts - toluene, trichloroethylene and the urinary excretion of line shows the values at the low dose rate. ethylene, and $n$-hexane - on the end
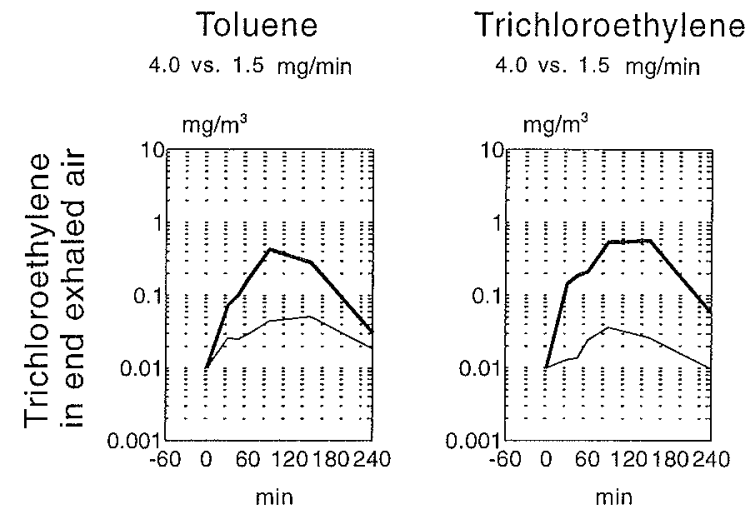

n-Hexane

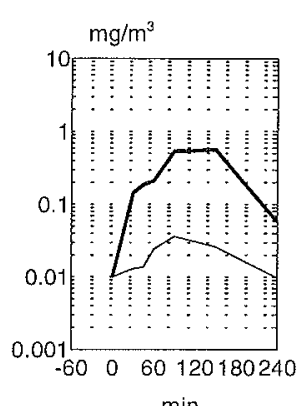

1.0 vs. $0.3 \mathrm{mg} / \mathrm{min}$
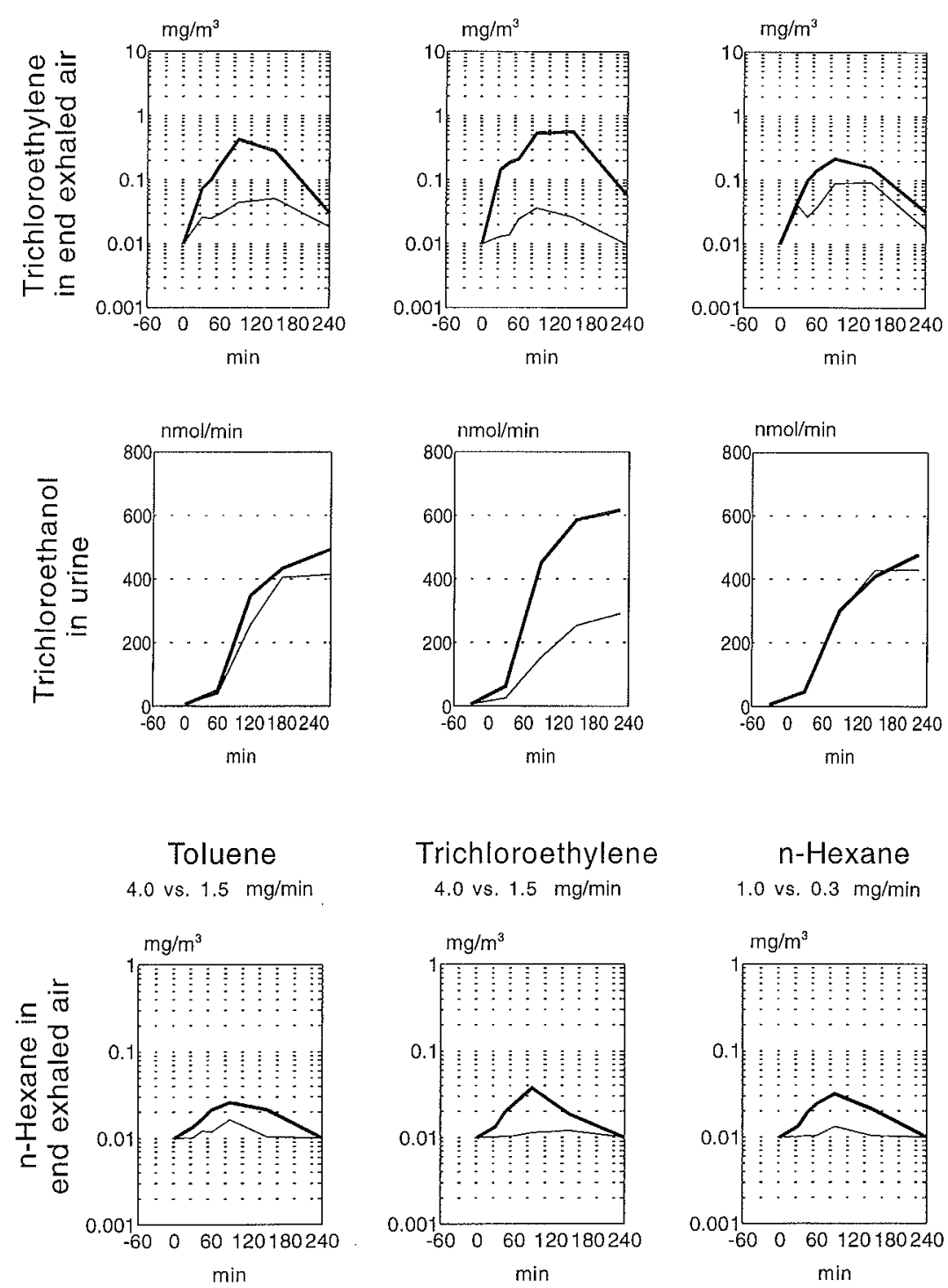

n-Hexane

1.0 vs. $0.3 \mathrm{mg} / \mathrm{min}$
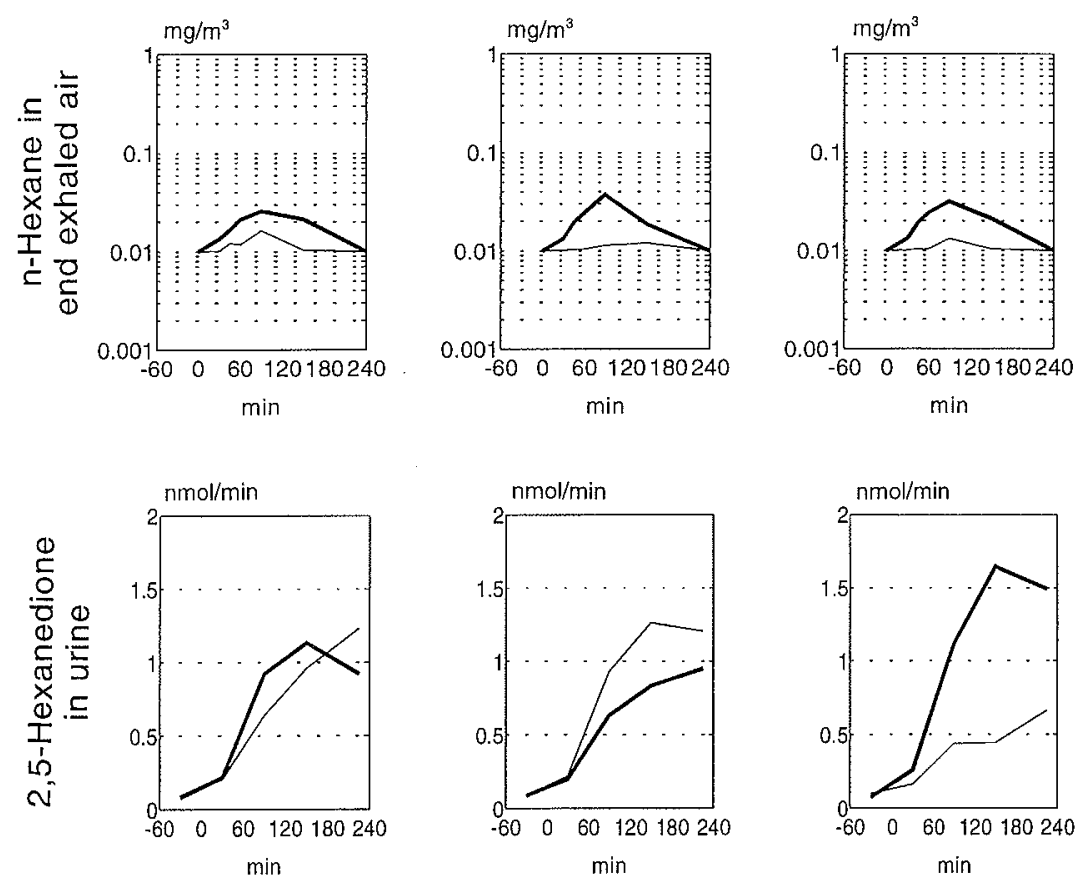

of the toluene dose after correction for preexposure excretion, while the excretion of $o$-cresol varied between $0.04 \%$ and $0.13 \%$ of the dose. TCE varied from $6.0 \%$ to $7.9 \%$, and the TCA excretion from $0.19 \%$ to $0.84 \%$ of the dose of trichloroethylene. 2,5-Hexanedione varied from $0.021 \%$ to $0.132 \%$ of the n-hexane dose. There was no statistically significant correlation between the individual excretions of the different metabolites or between the end exhaled concentrations and the metabolite excretion of the 3 substances. 


\section{Discussion}

In accordance with our previous study, this study showed that the hepatic extraction ratios or "first pass" effect of all the substances were very high but with a relatively well defined threshold. The exact level of this threshold cannot be calculated, but a change in the dose rate of any of the substances increased the end exhaled concentration of all 3 substances, and therefore the threshold is probably close to the lowest combined dose rate given.

At least toluene and trichloroethylene had an abundant effect on the end exhaled concentrations of the other substances, while the effect of $n$-hexane was smaller, probably because of the lower dose rate.

Quantitatively, measured by the change in urinary excretion of the metabolites, these dramatic effects on end exhaled concentrations reflect metabolic inhibition of only a few percent, and the only significant inhibition was the effect of n-hexane on the excretion of the main toluene metabolite, hippuric acid. A lengthening of the exposure period and thereby an increase in the total dose, however, may give rise to more significant interactions on the excretion of metabolites.

The rate-limiting step in the metabolism of the 3 substances is probably the initial hydroxylation mediated by the cytochrome-P450 system. Several different isoenzymes may be involved. For toluene CYP2E1 and CYP2B6 are involved in the side chain oxidation (resulting in hippuric acid) but not in the ring oxidation to $o$-cresol, where the primary enzyme in the rat is CYP2A1/2 (13). The oxidation of trichloroethylene to chloral hydrate is primarily catalyzed by CYP2E1 $(14,15)$, although other isoenzymes are involved, too. The hydroxylation of n-hexane is less well described. It is probably mediated both by a member of the CYP2B family (16) and by CYP2E1 (17).

CYP2E1 may therefore be the key enzyme, having the lowest $\mathrm{K}_{\mathrm{m}}$. This would imply a considerable inducibility of solvent metabolism by alcohol, at least in dose rates exceeding the threshold of flow-limited metabolism. Tardif et al (18) have shown that ethanol induces the metabolism of inhalation of $400 \mathrm{ppm}$ xylene in volunteers, while there was no effect at $100 \mathrm{ppm}$. In light of the results of our study, their results can be interpreted as an inducibility seen only when the flow limitation is exceeded.

The considerable differences in the metabolite excretion rates between the low and high dose rates of all the solvents indicate that the metabolism of the solvents was far from saturated. This phenomenon probably also explains the individual variation and the lack of correlation between the different measurements for the same person. The sharp increase in end exhaled air concentrations as the dose rates increase may be caused by a zoning or heterogeneity in the liver and thereby by a concentration gradient in hepatic sinusoid from the portal area to the central vein, which is also seen in other enzyme systems (19). Another possible model is the "parallel-tube" or sinusoidal perfusion model of liver metabolism (20).

The practical implication of our study on the evaluation of the exposures to mixtures of solvents in workplaces is the need to take into account interaction phenomena. The interactions are highly dose dependent and therefore of less importance at concentrations below the actual occupational exposure limits. This result is in accordance with studies of toluene and xylene where exposures to $50 \mathrm{ppm}$ toluene and 40 ppm xylene did not interfere with each other, while exposures at about 100 ppm of the 2 substances did $(12,21)$. However the mutual inhibition of toluene, trichloroethylene, and n-hexane was much smaller than the inhibition of low and moderate oral doses of ethanol on toluene and trichloroethylene; this finding is of considerable importance for the biologically effective dose $(5,22)$.

\section{Acknowledgments}

The experiment was skillfully conducted by Kate Westergaard and Said Rokny, both laboratory technicians, while the analysis of the metabolites was carried out at Miljø-Kemi A/S, DK-8464 Galten by Niels Hauns $\varnothing$, Msc; 2,5-hexanedione was analyzed at the Coronel Laboratories of the University of Amsterdam under the supervision of Hans Opdam, $\mathrm{PhD}$.

The study was supported by the Danish Working Environment Fund (grant no 1991-36), the Danish Medical Research Council (grant no 12-0364-1), and the Health Insurance Foundation (grant no 11/84 -90).

\section{References}

1. Toftgård R, Gustafsson J- $\AA$. Biotransformation of organic solvents: a review. Scand J Work Environ Health 1980;6:1-18.

2. Bælum J. Human solvent exposure: factors influencing the pharmacokinetics and acute effects. Pharmacol Toxicol 1991;68 suppl 1:1-36.

3. Sato A, Nakajima T, Fujiwara Y, Murayama N. A pharmacokinetic model to study the excretion of trichloroethylene and its metabolites after an inhalation exposure. Br J Ind Med 1977;34:56-63.

4. Perbellini L, Brugnone F, Pastorelli G, Grigolini L. Urinary excretion of $\mathrm{n}$-hexane metabolites in rats and humans. Int Arch Occup Environ Health 1979;42:349-54.

5. Bælum J, Mølhave L, Honoré Hansen S, Døssing M. Hepatic metabolism of toluene after gastrointestinal uptake in humans. Scand J Work Environ Health 1993;19:55-62.

6. Arbejdstilsynet [the Danish Labour Inspection]. Grænseværdier for stoffer og materialer [Occupational exposure limits]. Copenhagen: Arbejdstilsynet, 1992. At anvisning $\mathrm{Nr}$ 3.1.0.2.

7. Montgomery DC. Design and analysis of experiments. Second edition. New York (NY): John Wiley and Sons, 1984.

8. Veulemans H, Van Vlem E, Janssen H, Masschelein R, Leplat A. Experimental human exposure to $n$-hexane: study of the uptake and elimination, and of $n$-hexane concentration in peripheral venous 
blood. Int Arch Occup Environ Health 1982;49:251—63.

9. Sherwood RJ. Ostwald solubility coefficients of some industrially important substances. Br J Ind Med 1976;33:106-7.

10. Hansen SH, Døssing M. Determination of urinary hippuric acid and o-cresol, as indices of toluene exposure, by liquid chromatography on dynamically modified silica. J Chromatograph 1982;229:1418.

11. Christensen JM, Rasmussen K, Købben B. Automatic headspace gas chromatographic method for the simultaneous determination of trichloroethylene and metabolites in blood and urine. J Chromatograph 1988;442:317-23.

12. Tardif R, Laparé S, Plaa GL, Brodeur J. Effect of simultaneous exposure to toluene and xylene on their respective biological exposure indices in humans. Int Arch Occup Environ Health 1991;63:27984.

13. Nakajima T, Wang R, Elovaara E, Park SS, Gelboin HV, Vainio H. A comparative study on the contribution of cytochrome P450 isozymes to metabolism of benzene, toluene and trichloroethylene in rat liver. Biochem Pharmacol 1992;43(2):251-7.

14. Nakajima T, Wang R, Katakura Y, Kishi R, Elovaara E, Park SS, et al. Sex-, age- and pregnancy-induced changes in the metabolism of toluene and trichloroethylene in rat liver in relation to the regulation of cytochrome P450IIE1 and P450IC11 content. J Pharmacol Exp Ther 1992;261(3):869-74.

15. Tassaneeyakul W, Birkett DJ, Edwards JW, Veronese ME, Tukey $\mathrm{RH}$, Miners JO. Human cytochrome $\mathrm{P} 450$ isoform specificity in the regioselective metabolism of toluene and $0-, \mathrm{n}$ - and $\mathrm{p}$-xylene. $\mathrm{J}$
Pharmacol Exp Ther 1996;276(1):101-8.

16. Toftgård R, Haaparanta T, Eng L, Halpert J. Rat Lung and liver microsomal cytochrome P-450 isozymes involved in the hydroxylation of $\mathrm{n}$-hexane. Biochem Pharmacol 1986;35(21): 3733-8.

17. Lapadula DM, Habig C, Gupta RT, Abou-Donia MB. Induction of cytochrom $\mathrm{P} 450$ izoenzymes by simultaneous inhalation exposure of hens to n-hexane and methyl iso-buthyl ketone (MiBK). Biochem Pharmacol 1991;41(6/7):877-83.

18. Tardif R, Sato A, Laparé S, Brodeur J. Ethanol induced modification of $m$-xylene toxicokinetics in humans. Occup Environ Med 1994;51:187-91.

19. Quistorff B. Metabolic heterogeneity of liver parenchymal cells; investigated by digitonin perfusion techniques. Copenhagen (Denmark): Institute for Medical Biochemistry and Genetics, University of Copenhagen, 1994.

20. Bass L, Keiding S, Tygstrup N. Enzymatic elimination of substrates flowing through the intact liver. J Theor Biol 1976;61:393-409.

21. Wallén M, Holm S, Byfält Nordqvist M. Coexposure to toluene and p-xylene in man: uptake and elimination. Br J Ind Med 1985;42:111-6.

22. Müller G, Spassowski M, Henschler D. Metabolism of trichloroethylene in man III: interaction of trichloroethylene and ethanol. Arch Toxicol 1975;33:173-89.

Received for publication: 31 January 1997 